\title{
Special aspects of the development of harmful objects on the grape mother plants of the original category in the conditions of the Rostov region
}

\author{
Natalia Arestova*, and Irina Ryabchun \\ All-Russian Research Ya. I. Potapenko Institute for Viticulture and Winemaking - Branch of the \\ Federal State Budget Scientific Institution "Federal Rostov Agricultural Research Center", 166 ave. \\ Baklanovsky, Novocherkassk, 346421, Russia
}

\begin{abstract}
The results of monitoring the distribution of phytopathogens and pests under conditions of maintaining mother plantations, improved and propagated in tissue culture, category original in the conditions of the Nizhne-Kundryuchensky sand massif in Rostov region, are presented. In the basic vineyard, conditions are met that exclude the possibility of secondary infection of healthy plants and make it possible to obtain planting material of the elite category. Vineyards have not been cultivated on these areas for at least 10 years, which reduces the risk of the presence of outbreaks of harmful organisms specific to grapes. Before establishing of the basic vineyard, the soil samples were diagnosed for the presence of harmful organisms in it. The results of the survey showed the absence of such pests in the soil as the larvae of scoops, beetles, click beetles, as well as bacterial diseases and nematodes. According to the results of monitoring observations, it was revealed that the mother plants of the basic plants of the ARRIV\&W - Branch of FSBSI FRANC are mainly spread by the following fungal diseases: powdery mildew, black spot, downy mildew, the intensity of which, due to regular protective treatments, did not exceed 2.5 points. The harmfulness of the main insects (leafhoppers, ticks, thrips) on the basic vineyard, is economically insignificant. Studies confirm the absence of migration of the leaf form of phylloxera. Pesticides were used during protective measures, guided by the principle of rotation of active substances and with the use of an active substance of one name no more than twice a season.
\end{abstract}

\section{Introduction}

An important condition for the longevity, stable productivity of vineyards is the establishment of vineyards with high-quality, virus-free planting material. The quality of the planting material is determined by the following biological categories: original - a healthy, virus-free planting material (in our case with applying in vitro culture); elite - virus-free

\footnotetext{
*Corresponding author: zash.arestova@yandex.ru
} 
material, propagated on a mother planting of the original category and reproductive obtained on an elite mother planting, intended for the establishment of industrial plantings.

The complex of harmful objects in the Don vineyards is diverse and is largely determined by the edaphoclimatic conditions of the region. The interaction of a complex of factors of different nature leads to a change in the degree of harmfulness of living organisms in the composition of agrocenoses, which has been observed in recent years.

There have been significant changes in the spread and harmfulness of many harmful objects caused by climate warming, changes in economic activity and disruption of the natural vegetation cover. Some species have lost their economic importance, while others have settled, having mastered new territories. Rare and uncharacteristic for the region grape diseases are more common. The reason for the aggravation of the situation is the changes occurring in the biology of pathogens, their high plasticity and adaptability [1-5].

For the establishment of grapes mother plantings of various biological categories, only recovered grape plants should be used. Unsuitable for reproduction are grape plants affected by viral, phytoplasmic diseases, especially those that are quarantine objects. These diseases negatively affect the plant - their adaptability to unfavorable environmental factors decreases, the quantitative and qualitative characteristics of the crop deteriorate, and the life cycle of plants is reduced. Problems with the quality of planting material and, as a result, ineffective management of vineyards were noted not only in Russian nursery farms, but also in developed western wine-growing regions [6-8].

The control of pests and diseases in the mother planting presupposes a special system for monitoring the development and spread of harmful organisms and protecting against them. In this case, the main attention is paid to measures to prevent the penetration of these organisms into the territory of the mother planting. The solution to this problem is primarily achieved by observing quarantine measures, as well as preventing the emergence of development outbreaks of harmful organisms by timely processing of plantings with highly effective protective and eradicating pesticides. In developed wine-growing regions, comprehensive standards for the production of high-quality planting material have been developed, in which procedures have been developed to comply with quarantine and phytosanitary measures on mother plantings of various biological categories [9-12].

Currently, one of the methods of obtaining high-quality planting material is the biotechnological method of meristems culture with further micropropagation, which allows not only to improve health, but also to rapidly multiply valuable varieties and forms of grapes, which makes it possible to maximize the intensification of the nursery process [13$15]$.

In the field conditions of mother planting management, vegetatively propagated grape plants, recovered with applying a meristem culture, can be infected by quarantine objects. In this connection, it is necessary to develop a system of measures regulating all protective requirements in the mother planting and the production of planting material corresponding to the original biological category. Russian scientists have developed quarantine measures based on regulatory documents and materials of the FS of Rosselkhoznadzor (state standards), including organizational, preventive and sanitary and hygienic requirements, the fulfillment of which is strictly mandatory both for the farm as a whole and for each employee.

Currently, there is no regulatory framework in the Russian Federation regulating the production of grapes virus-free planting material. The existing Federal law on seed production does not provide a legal basis for the development of modern nursery. There is a need to develop common Russian standards for quarantine and phytosanitary measures for the production of planting material of the highest quality categories.

In this regard, the purpose of our research was to scientifically substantiate measures to prevent secondary infection of grape plants with quarantine diseases, curb the development 
and spread of harmful objects and preserve the status of the grapes mother planting in the "original" category.

\section{Materials and methods}

The mother planting of the original biological category was established in the Ust-Donetsk district of the Rostov region on the territory of the Nizhne-Kundryuchensky sand massif in 2003. The recovered plants were obtained using a meristem culture and adapted to field conditions by the scientists of the Institute. Grape plants were tested using PCR analysis.

The grapes mother plantations in the Rostov region meet the quarantine measures required for the production of certified grape planting material: provided spatial isolation from nearby vineyards at a distance of at least $45-60 \mathrm{~km}$, limited movement of people and vehicles. Vineyards have not been cultivated on these areas for at least 10 years, which reduces the risk of outbreaks of harmful objects specific to grapes. The mother planting is located on a sand massif, which prevents the development of insect-vestors, as well as phylloxera. This makes it possible to cultivate both rootstock and own-root varieties.

The climatic conditions of the mother planting are characterized by an average sum of active temperatures of $3200^{\circ} \mathrm{C}$, an average annual precipitation of $430 \mathrm{~mm}$. The groundwater depth is at the level of $1.1-2.5 \mathrm{~m}$.

Prevention of secondary infection of plants with harmful organisms was solved with the help of monitoring surveys of plantings of the mother plantation and the surrounding area $(50 \mathrm{~m})$, as well as preventive protective measures, the frequency of which depends on weather conditions. Also, during the growing season, a mandatory two-time visual examination of all grapes mother plants during the period of flowering and veraison was carried out for the presence of harmful objects - viral, bacterial diseases and mycoses. Also, control over pests-vectors of infection was carried out with the help of regular examinations and preventive treatments of plantings, including the surrounding area of spatial isolation.

Plants with signs of dangerous harmful diseases were subject to mandatory grubbing. Determination of the pest species was clarified with the help of keys, reference books and laboratory studies.

The application of pesticides against harmful objects was conducted according to state regulations. An important factor was the local application of pesticides with the destruction of harmful objects primary populations before their dispersal, in the phase of concentration.

The factor of the development of resistance to the applicated pesticides was taken into account when the regulations for protective measures were compiled by.

The use of multicomponent mixtures, consisting of systemic and contact fungicides, with the use of agents of the same chemical class no more than 1-2 times per season, contributes to an increase in the efficacy of protection and anti-resistance strategy.

Difficulty is caused by chemical treatment of secretively living pests, such as scoops, beetles, etc., therefore, an important part of protective measures is the agrotechnical method, which makes it possible to realize the adaptive potential of grape plants at all stages of organogenesis.

Subject to the correct choice of agents and methods of their application, the chemical method of controlling harmful organisms remains the most effective and economic so far. Biological agents are sensitive to temperature and humidity conditions and, therefore, are ineffective in the frequent stressful meteorological conditions of the Rostov region. As a consequence, the application of chemicals is dominant. 


\section{Results and Discussion}

We have established that the main phytopathogens on the mother planting of recovered plants are: downy mildew (Plasmopara viticola), powdery mildew (Uncinula necator), black spot (Phomopsis viticola). In different years, the infestation of grape plants with these diseases, despite the presence of unstable varieties, did not exceed 2.5 points, which can be explained by the efficacy of protective measures (Fig. 1).

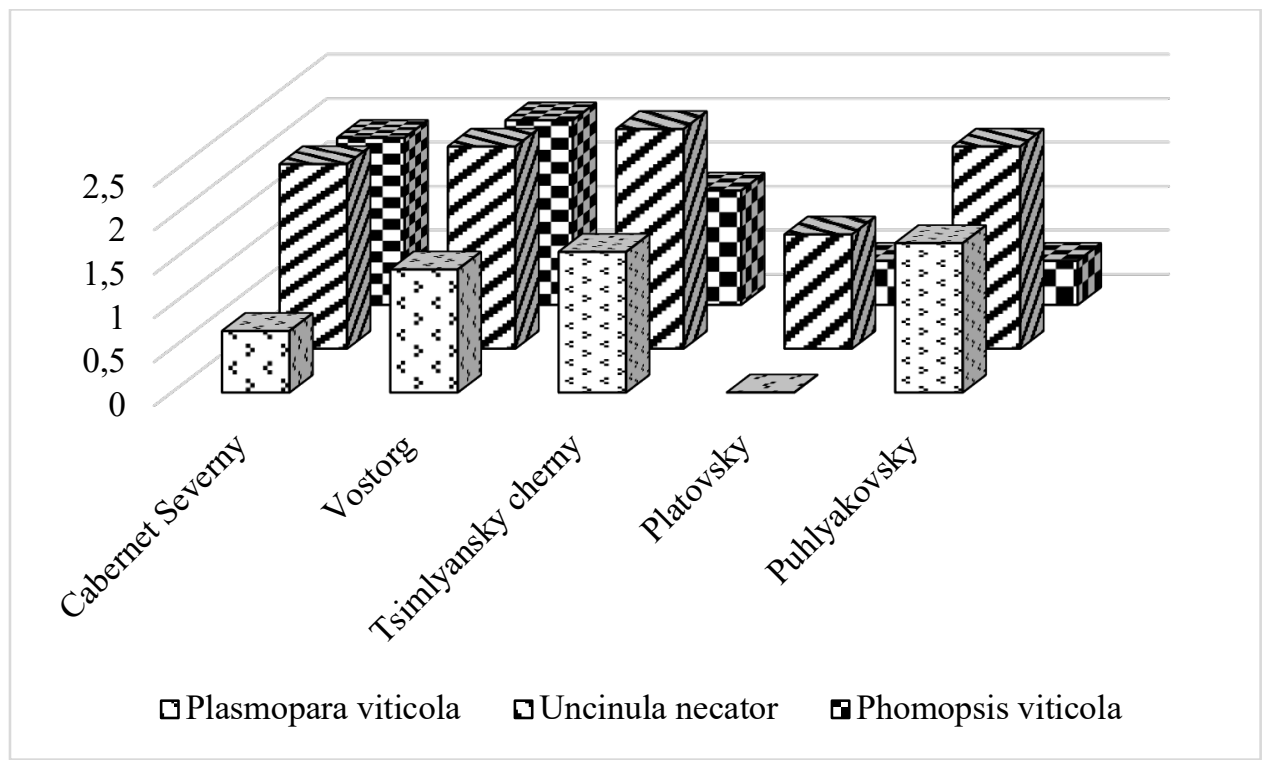

Fig. 1. Infection of plants of various varieties by major diseases in 2014-2018.

The presence of other diseases was not recorded every year and was not significant, with the exception of single plants with crown gall (Agrobacterium tumefaciens), which were subject to compulsory uprooting and burning.

Any signs of diseases (viral and phytoplasmic) requiring special control in the mother planting were not identified.

In plants of rootstock varieties, the infection with powdery mildew and downy mildew did not exceed one point; single plants with signs of crown gall were found, which were uprooted and burned. There were no signs of other phytopathogens, as well as viral and phytoplasmic diseases.

Due to the existing threat of entry of harmful sucking insects from neighboring territories and their spread in the agrocenosis of the mother planting, including leafhoppers, ticks, thrips, etc., we regularly monitored their development and distribution. The harmfulness of the identified insects does not exceed a significant threshold, but it differs from year to year with a tendency to slightly increase (Fig. 2). 


\section{8}

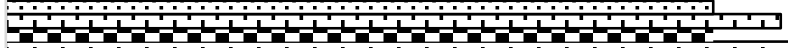

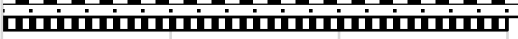

2017

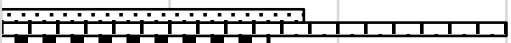

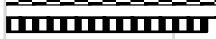

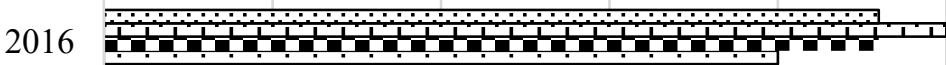

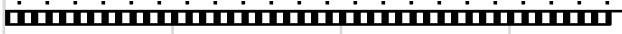

2015

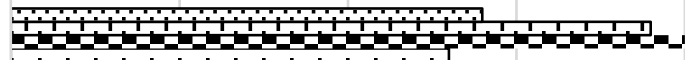

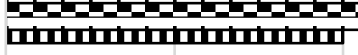

2014

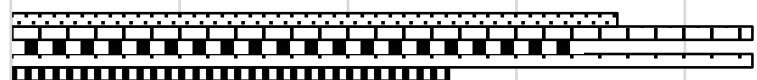

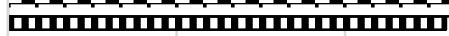

0

$$
0,5
$$

1

1,5

2

2,5

3

Damage degree, score

$\Xi$ Drepanothrips reuteri

$\square$ Edwardsiana rosae
口Eriophyes vitis Pgst.

๘ Oecanthus pellucens

r Ceresa alta

Fig. 2. Degree of harmfulness of insects in dynamics, 2014-2018.

Based on the results of excavations and phytosanitary monitoring of rootstock grape varieties, we noted the absence of root and leaf forms of phylloxera (Dactylosphaera vitifoliae)

Under meteorological conditions not conducive to the active development of phytopathogens, protective treatments with fungicides were carried out in the following phases of the growing season: sap flow; before flowering; after flowering; small berries; berry growth; veraison. With the threat of epiphytoties, spraying of plants on the mother planting was carried out more often.

As the results were indicated that the greatest efficacy of protective measures is achieved after applying combined fungicides in the first half of the growing season, when the shoots are actively developing, and contact ones - after the cessation of growth. The advantage of systemic components is that they quickly penetrate into plant tissues, are inaccessible to rain, and retain their effectiveness for a long time (10-14 days). A significant drawback is resistance that easily arises to them.

Tank mixtures of pesticides were applied during protective treatments, guided by the principle of compatibility and rotation of active substances. An active substance of one name, included in the list of permitted for use in the Russian Federation, was used no more than twice a season. The complex of protective measures against harmful organisms also includes a disinfection barrier, which prevents their spread by vehicles and people.

\section{Conclusions}

The data obtained as a result of research allows us to conclude that the agrocenosis of vineyards in the Rostov region is characterized by a large species diversity of harmful objects. The pathogens of the following diseases are distinguished by developmental stability in the agrocenosis: downy mildew (Plasmopara viticola), powdery mildew (Uncinula necator), black spot (Phomopsis viticola), as well as pests: thrips (Drepanothrips reuteri), various species of leafhoppers (Cereswardsa rosae alta), felt mite (Eriophyes vitis), etc. There is a tendency towards their growth.

The developed system of phytosanitary control on the mother planting of the original 
biological category made it possible to restrain the development of seasonal fungal diseases up to 2.5 points, including unstable varieties, to exclude their re-infection with viruses, phytoplasmas and other harmful organisms, as the result ensuring further propagation of practically healthy grape planting material.

\section{References}

1. R. Billones-Baaijens, H. J. Ridgway, E. E. Jones, R. H. Cruickshank, M. V. Jaspers, Eur. J. Plant Pathol., 135, 175-185 (2013). https://doi.org/10.1007/s10658-012-0076-4

2. N. O. Arestova, I. O. Ryabchun, Pomiculture and small fruits culture in Russia, 58, 102108 (2019). https://doi.org/10.31676/2073-4948-2019-58-102-108

3. B. Gabel, BIO Web Conf., 15, 01020 (2019). https://doi.org/10.1051/bioconf/ 20191501020

4. L. Gierl, M. Fischer, Vitis, 56(3), 103-110 (2017). https://doi.org/10.5073/vitis. 2017.56.103-110

5. M. Fischer, P. Schneider, C. Kraus, M. Molnar, C. Dubois, D. d'Aguiar, N. Haag, Vitis, 55(4), 145-156 (2016). https://doi.org/10.5073/vitis.2016.55.145-156

6. D. Gramaje, S. Di MarcoPhytopathol.Mediterr., 54(2), 313-324, (2015). http://doi.org/10.14601/Phytopathol_Mediterr-16317

7. H. Waite, P. May, G. Bossinger, Phytopathol. Mediterr., 52(2), 369-379 (2013). 10.14601/Phytopathol_Mediterr10667https://oajournals.fupress.net/index.php/pm/article/view/5527/5525

8. R. Billones-Baaijens, H. J. Ridgway, E. E. Jones, M. V. Jaspers, Eur. J. Plant. Pathol. 141, 267-279 (2015). https://doi.org/10.1007/s10658-014-0540-4

9. H. Waite, M. Whitelaw-Weckerta, P. Torleya, New Zeal. J. Crop Hort. Sci., 43(2), 144-161 (2015). https://doi.org/10.1080/01140671.2014.978340

10. D. S. Grohs, M. A. K. Almança, T. V. M. Fajardo, F. Halleen., A. Miele,Rev. Bras. Frutic., 39(4), e-760(2017). https://doi.org/10.1590/0100-29452017760

11. H. Waite, J. Armengol, R. Billones-Baaijens, D. Gramaje, F. Halleen, S. Di Marco, R. Smart, Phytopathol. Mediterr., 57(3), 384-398 (2018). https://doi.org/10.14601/Phytopathol_Mediterr-22772

12. C. Pintos, V. Redondo, D. Costas, O. Aguín, P. Mansilla, Phytopathol. Mediterr., 57(3), 407-424 (2018). http://doi.org/10.14601/Phytopathol_Mediterr-22964

13. B. Kinfe, T. Feyssa G. Bedada, Afr. J. Biotechnol, 16(43), 2083-2091 (2017). https://doi.org/10.5897/AJB2016.15803

14. M. Ur. Rahman, M. Hanif, K. Shah, B. Ahmad, X. Wang, Vitis, 58(4), 123-130 (2019). https://doi.org/10.5073/vitis.2019.58.123-130

15. L.-H. Huang, X.-J.Ao, H. Shan, H.-X. Li, W.-X. Yang, Vitis, 56(2), 71-77 (2017). https://doi.org/10.5073/vitis.2017.56.71-77 